\title{
The Influence of the Type of Adhesive on the Properties of Sawdust Briquettes
}

\author{
Wijianto $^{1 *}$, Sarjito ${ }^{1}$, Nur Aklis ${ }^{1}$ Agus Dwi Anggono ${ }^{1}$, AgungSetyo Darmawan ${ }^{1}$ \\ ${ }^{1}$ Department of Mechanical Engineering, Faculty of Engineering \\ UniversitasMuhammadiyah Surakarta \\ wijianto@ums.ac.id
}

\begin{abstract}
The aim of this research is to know the effect of binders variation such as starch, used oil, coconut shell tar to the properties of sawdust briquette for instance volatile meter, ash content, fixed carbon content, water content, heating value, specific weight, and density. By composition $50 \%$ matrix and $50 \%$ binder, Sawdust crushing first in order to get 20 mesh, after that sawdust briquettes was made using a briquette pressing device with a pressure of $30 \mathrm{~kg} / \mathrm{cm}^{2}$. The result of the analysis obtained that sawdust briquette using all variation of binders have heating value more than 4000 $\mathrm{Cal} / \mathrm{gr}$, that mean these briquette already meet the requirement for briquette production.Briquette with used oil as binder having better physical and mechanical properties compared by adhesive from starch and coconut shell tar.
\end{abstract}

Key words:Sawdust briquette, Binder, starch, used oil, coconut shell tar

\section{INTRODUCTION}

Indonesia is a developing country with agriculture and plantation sectors as the main priority in their development. Usually, agriculture and plantation sector always produce biomass waste. Biomass waste rarely be used maximally. Biomass and waste biomass can become source of alternative energies to substitute energies from fossil fuels[1].Recently, renewable energy sources should be effectively utilized in order to meet the rapidly increasing energy demand and has an even more important role. Research about sawdust and neem powder as binder give result that neem powder as binder for briquette form sawdust can increasing the strength and having a little reduction in burning rate[2]. The main advantage using biomass as source of bioenergy products is have low bulk density, particularly for sawdust and wood chip[3]. Characteristics of different biomass briquettes such as sawdust, rice husks, peanut shells, coconut fibers and palm fruit fibers has done by Chin and Siddiqui[4]. The research applying differences die pressures for their experimentally. The result shows that the sawdust briquette has better overall handling characteristics than other.
Another research about process to made briquette from biomass already done by $\mathrm{Li}$ and Liu[5], using high pressure in range between $28 \mathrm{MPa}$ to $138 \mathrm{MPa}$, the performance of binderless briquette show thatthe strongest logs are made with the oak sawdust, cottonwood sawdust next and the least $\log$ with pine sawdust. Yaman et al.[6]have done research how to produce fuel briquettes from olive refuse and paper mill waste using difference pressure which was at range between $150 \mathrm{MPa}$ to $250 \mathrm{MPa}$. These research to obtain the maximum heating value, minimum ash content and maximum compressive strength optimization. The optimal values obtained for the studied briquetting process parameters are a compression force of $588.6 \mathrm{kN}$, a sawdust mass of $46.66 \%$ and a drying temperature of $22^{\circ} \mathrm{C}$ [7].

Zhang et al. [8]have declared that the briquette strength is improved by adding the bentonite, coal tar and/or polypropylene amide into rice straw-based binder. Ndiema et al. [9] have investigated and concluded that die pressure has a considerable effect on the size of biomass. Mani et al. [10]have investigated the specific energy required to produce the compact corn stoverbriquette and reported that the density increases with increase in pressure.

Binders or adhesive on briquette production from biomass,might have apositive outcome on the strength of the wood pellets, in a similar way to the adhesive resin used in the production of particleand fiber-boards. Starch, protein, fiber, fat/oil, lignosulfonate, bentonite and modified cellulose have been investigated as bindersto positively influence the durability of densified products[11]-[14].

The lower moisture content of sawdust briquette can produce lower cost as well[15]. Mechanical properties of sawdust briquette depend on press machine, type of wood and quantity of binder[15]. Material and process variables that could additionally influence the physical and mechanical characteristics of briquettes are compacting pressure, moisture content, particle size distribution of biomass raw material and temperature[16].

Wijianto et al. [17]have done research about mechanical characteristic of kokas briquette using variation of binder, the result of these research show that briquette with binder from tar have good quality and better impact 
pressure.Briquettes produced with the three binders (starch, enhanced treated biosolids and microalgae) show that briquette those containing the microalgae binder were found to be most durable, with a higher energy value, slower mass loss during briquette combustion, and a higher afterglow time[18].

High quality and storable briquettes can be produced from the blend of carbonized corncobs and cassava starch, corn starch and gelatin [19]. Tars obtained from bio-briquettes and from biomass-free briquettes reduces the amount of sulfur. The aromaticity of bio-tars was found to be lower than that of the tars from the biomass-free briquettes. They therefore contribute less to carcinogenicity, but they have more oxygenated groups[20].

\section{RESEARCH METHODOLOGY}

The first step of this research is to design and manufacture a briquette molding machine Fig. 1. This tool works by using hydraulic power. These briquette molding machine consisting of die and punch with briquette dimension $\varnothing 1$ in and 1 in high. In the next step is crushing sawdust and then filters it into 20 mesh. Mixing with binders is done by combining $50 \%$ of sawdust that has been meshed and 50\% of binder. Variation of adhesive are starch, tar and used oil. After becoming a dough, then briquette is molded with a pressure of $30 \mathrm{~kg} / \mathrm{cm}^{2}$. One process of molding can be produce 25 briquettes.

Drying is done until the water content in the briquettes is less than $20 \%$. Laboratory test is done to obtain percentage of volatile meter, fixed carbon, percentage of dust, water content, specific weight, and heating value every combination of briquette specimen.

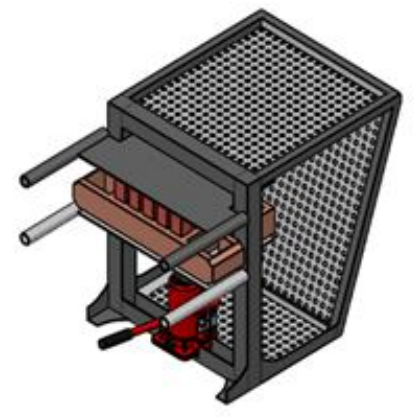

(a) Design of briquette molding

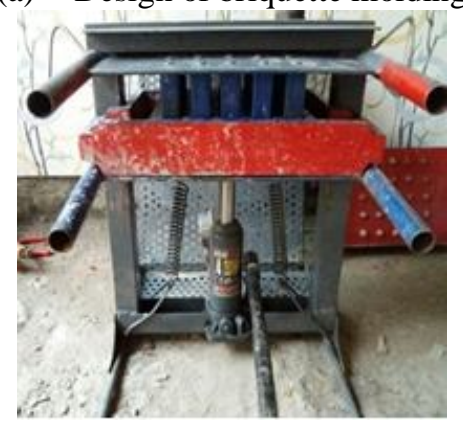

(b) Construction of briquette molding machine

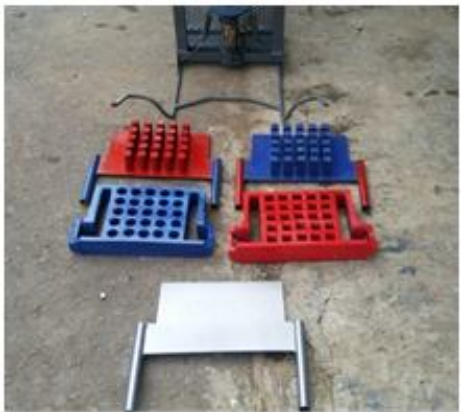

(c) Briquette molding

Figure 1: Briquette molding machine

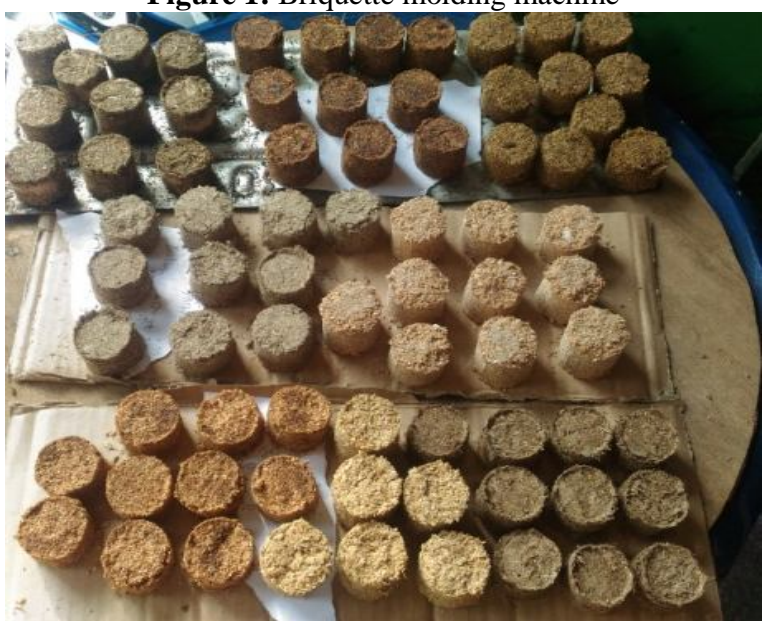

Figure 2: Briquette

Proximate analysis is an analysis conducted by testing the briquettes to obtain the chemical composition of the briquettes. This analysis includes water content, volatile matter content, ash content, and fixed carbon content. Volatile content is a number of substances that can evaporate as a result of decomposition of compounds other than water contained in briquettes. Ash content is the amount of remaining ash resulting from the briquette burning process. High ash content can reduce the heating value of the briquettes so that the quality of the briquettes will decrease. Fix carbon is a fixed carbon content in briquettes after the water content, volatile matter, and ash content are separated.

The heating value shows the amount of heat energy produced from the combustion process per unit mass of a fuel. The heating value determines the quality of a fuel where the higher the heating value, the better the quality of the briquette. The heating value can be obtained from various methods, one of which is by using the bomb calorimeter method. Water content is the amount of water contained in briquette. Briquette water content is the amount of water contained in each mass unit of the briquette. The water content of the briquette greatly affects the quality of the briquettes where the smaller the briquette's water content the higher the briquette's calorific value so that the quality of the briquettes is better. 
Wijianto et al., International Journal of Emerging Trends in Engineering Research, 8(9), September 2020, 5353 - 5356

Briquette density is a comparison between the density of briquettes with the density of water $\left(1 \mathrm{gr} / \mathrm{cm}^{3}\right.$ or $\left.1000 \mathrm{~kg} / \mathrm{m}^{3}\right)$. The specificity of the briquette affects the heating value of the briquette so that the greater the specific gravity of the briquette, the greater the heating value of the briquette. Density is the ratio between mass and object volume. Briquette density is influenced by the shape, size, and content of the briquettes themselves. Density affects the combustion process. The greater the density of the object, the greater its specific gravity, so the combustion rate will be longer. Density also affects the size of the heating value. The greater the density and the greater the specific gravity, the greater the caloric value [21-22].

This research refers to the quality standard of briquettes so that the briquettes produced can be classified as good quality briquettes or not, as can be seen at table 1 .

Table 1:Quality Standard for Briquette

\begin{tabular}{|l|l|}
\hline Testing parameters & Requirement \\
\hline Percentage of Water content & $<20 \%$ \\
\hline Percentage of dust content & $14-20 \%$ \\
\hline Heating Value & $>4000 \mathrm{kal} / \mathrm{gram}$ \\
\hline Pressure strength & $>20 \mathrm{~kg} / \mathrm{cm}^{2}$ \\
\hline
\end{tabular}

\section{RESULT AND DISCUSSION}

In order to get results in accordance with standards, it is necessary to using standard test number. Testing standards are the process of ensuring the quality of product samples against certain standard requirements.

Tabel 2:Standard testing number for briquette

\begin{tabular}{|l|l|}
\hline Testing Name & Standard Test Number \\
\hline Volatile matter test & ASTM D-3175 \\
\hline Ash content test & ASTM D-3174 \\
\hline Fixed carbon test & ASTM D-3172 \\
\hline Water content test & ASTM D-3173 \\
\hline Heating value test & ASTM 2015 \\
\hline Specific gravity test & ASTM D-2395 \\
\hline density & ASTM B-311-93 \\
\hline
\end{tabular}

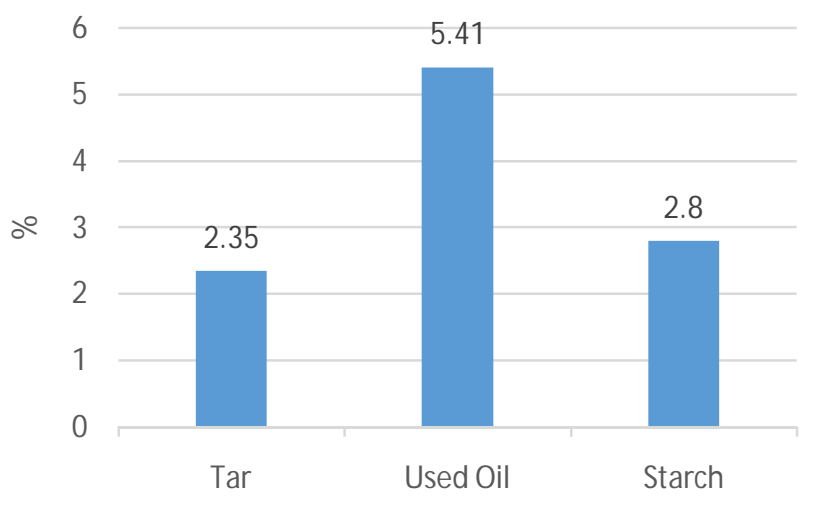

(a)

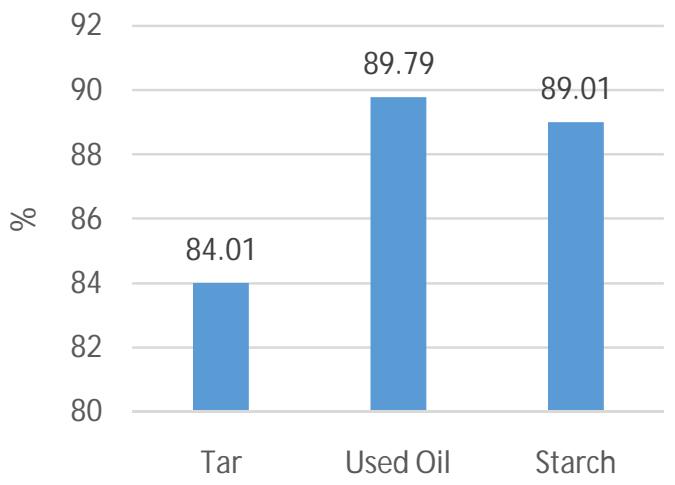

(b)

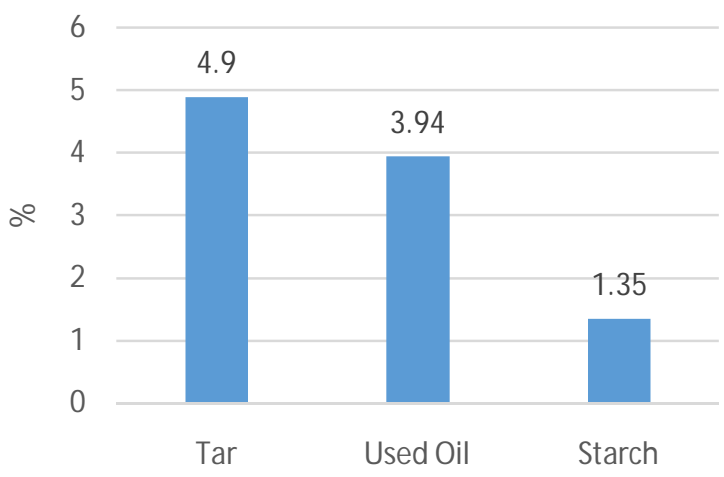

(c)

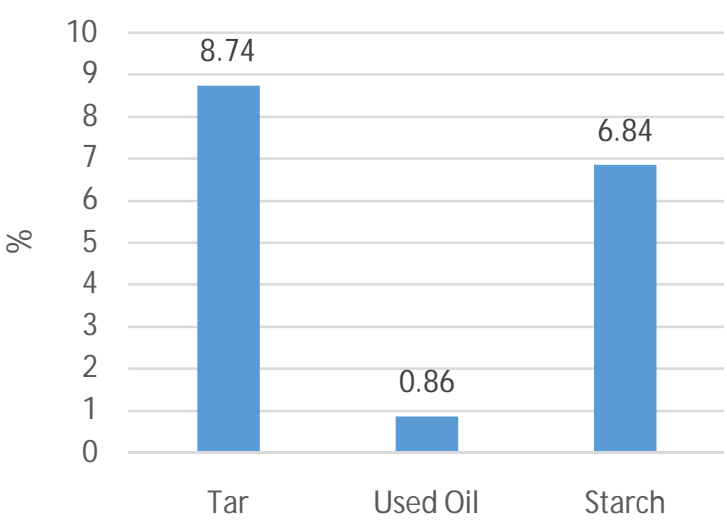

(d)

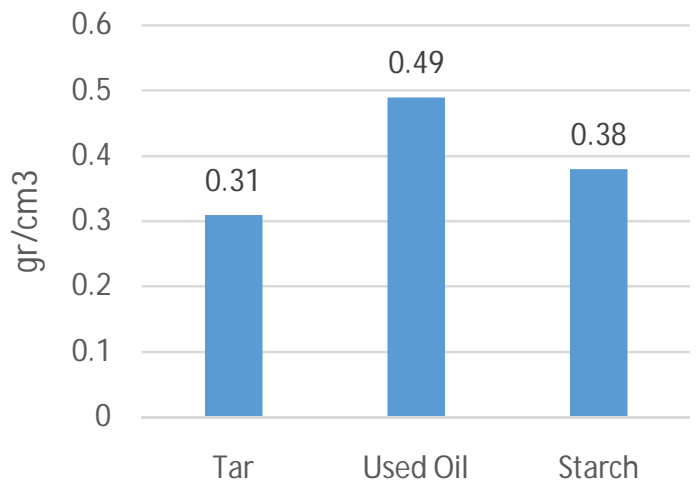

(e) 
Wijianto et al., International Journal of Emerging Trends in Engineering Research, 8(9), September 2020, 5353 - 5356

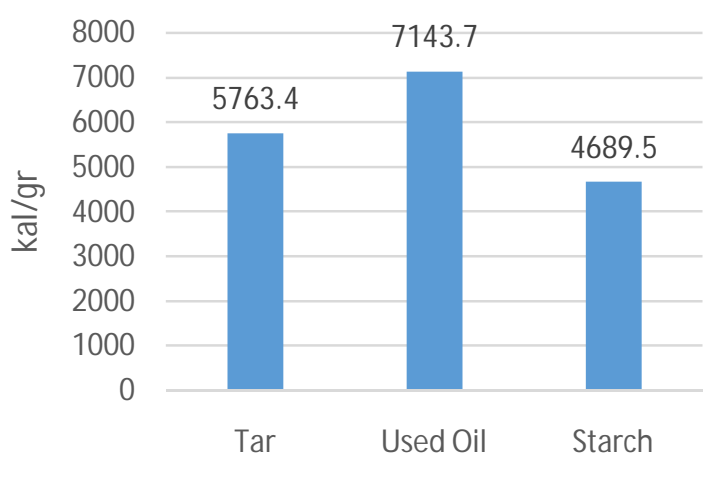

(f)

Figure 3: Result for testing of saw dust briquette with variation of adhesive are tar, used oil and starch.

(a) Water content test, (b) Volatile meter test, (c) Ash content, (d)

Fixed carbon, (e) Density, (f) Heating value

Fig. 3 shows the results of several sawdust briquette tests.According of fig. 3(a), it is clear that briquettes with adhesives from used oil have more percentage of water content. This briquette causes a longer for drying, compared to briquettes from tar and starch as their adhesives. Starch briquettes have the least moisture content, so it is fast in the drying process. This is in line to the percentage volatile meter fig. 3 (b) and density fig. 3(e) of the briquette. Indeed, the high percentage of volatile meter can showing that briquettes will be more flammable. On the other hand, briquette with the highest ash content is found in briquettes with tar as adhesive fig. 3(c). High of percentage ash content will cause a decrease in briquette quality because it will reduce the heating value.

The density of Briquette with used oil as adhesive is also higher 3(e). As can be seen from fig. 3(d), briquette with adhesive from used oil have lowest percentage of fixed carbon, which is reach $0.86 \%$, compared with others adhesive that reach more than $6 \%$. In line of this result, so with low fixed carbon, comparable to high heating value, which reaches above $7000 \mathrm{Cal} / \mathrm{gr}$. Briquettes with tar as adhesive have a lower heating value which is $5763.4 \mathrm{Cal} / \mathrm{gr}$ followed by briquettes with starch as adhesive.

With a heat values more than $4000 \mathrm{Cal} / \mathrm{gr}$ of the entire briquette specimens, so that the briquettes from this research are feasible to be mass produced and can be substitute for fuel derived from oil and gas.

\section{CONCLUSION}

According on the results of research and analysis above, the following conclusions can be obtained:

1. In proximate testing, the highest volatile matter content was obtained in the testing of briquettes with used oil as adhesives at $89.79 \%$ and the smallest levels of volatile substances were obtained on tar as adhesives at $84.01 \%$. The largest ash content was obtained in the briquette test with tar as adhesive at $4.9 \%$ and the smallest ash content was obtained at starch as adhesive at $1.34 \%$. The highest bonded carbon content was obtained in the testing of briquettes with tar adhesive of $8.74 \%$, and the lowest bound carbon content was obtained in used oil adhesives of $0.86 \%$.

2. The greatest water content was obtained in the testing briquettes with oil adhesive at $5.41 \%$, and the smallest water content was obtained at tar adhesive at $2.35 \%$. The highest heating value was obtained from the testing of teak sawdust briquettes with oil adhesive of $7143.67 \mathrm{Cal} / \mathrm{gr}$, and the smallest heating value was obtained from the starch adhesive glue of 4689.45 $\mathrm{Cal} / \mathrm{gr}$. The water content and heating value of briquettes with variation of adhesive from tar, starch and used oil have met the briquette quality standards.

3. The largest specific gravity was obtained in testing briquettes with used oil adhesives of 0.61 and the smallest specific gravity obtained on tar adhesives of 0.54 . The largest mass meeting was obtained in the testing of briquettes with oil adhesives of $0.49 \mathrm{gr} / \mathrm{cm}^{3}$, and the smallest specific gravity was obtained on tar adhesives of $0.31 \mathrm{gr} / \mathrm{cm}^{3}$.

\section{ACKNOWLEDGEMENT}

Authors would like to appreciate and thank to Directorate General of Research, Technology and Higher Education, Ministry of Research, Technology and Higher Education of the Republic of Indonesia. This Research is financially supported by PenelitianTerapanUnggulanPerguruanTinggi (PTUPT) Project at the fiscal year 2019 with contract number 199.59/A.3-III/LPPM/V/2019.

\section{REFERENCES}

1. L. Axelsson, M. Franzén, M. Ostwald, G. Berndes, G. Lakshmi, and N. H. Ravindranath, "Perspective: Jatropha cultivation in southern India: Assessing farmers' experiences," Biofuels, Bioprod. Biorefining, vol. 6, no. 3, pp. 246-256, 2012.

2. T. Rajaseenivasan, V. Srinivasan, G. Syed Mohamed Qadir, and K. Srithar, "An investigation on the performance of sawdust briquette blending with neem powder," Alexandria Eng. J., vol. 55, no. 3, pp. 28332838, 2016.

3. E. Shahab Sokhansanj, P.Eng., University of British Columbia Jim Fenton, President, Jim Fenton and Associates, "Cost benefit of biomass supply and preprocessing," A BIOCAP Research Integration Program, 2016.

4. O. C. Chin and K. M. Siddiqui, "Characteristics of some biomass briquettes prepared under modest die pressures," Biomass and Bioenergy, vol. 18, no. 3, pp. 223-228, 2000.

5. Y. Li and H. Liu, "High-pressure densification of wood residues to form an upgraded fuel," Biomass and Bioenergy, vol. 19, no. 3, pp. 177-186, 2000.

6. S. Yaman, M. Şahan, H. Haykiri-Açma, K. Şeşen, and S. Küçükbayrak, "Production of fuel briquettes from olive refuse and paper mill waste," Fuel Process. Technol., vol. 68, no. 1, pp. 23-31, 2000. 
7. B. Lela, M. Barišić, and S. Nižetić, "Cardboard/sawdust briquettes as biomass fuel: Physical-mechanical and thermal characteristics," Waste Manag., vol. 47, pp. 236-245, 2016.

8. X. Zhang, D. Xu, Z. Xu, and Q. Cheng, "The effect of different treatment conditions on biomass binder preparation for lignite briquette," Fuel Process. Technol., vol. 73, no. 3, pp. 185-196, 2001.

9. C. K. W. Ndiema, P. N. Manga, and C. R. Ruttoh, "Influence of die pressure on relaxation characteristics of briquetted biomass," Energy Convers. Manag., vol. 43, no. 16, pp. 2157-2161, 2002.

10. S. Mani, L. G. Tabil, and S. Sokhansanj, "Specific energy requirement for compacting corn stover," Bioresour. Technol., vol. 97, no. 12, pp. 1420-1426, 2006.

11. J. L. Briggs, D. E. Maier, B. A. Watkins, and K. C. Behnke, "Effect of ingredients and processing parameters on pellet quality," Poult. Sci., vol. 78, no. 10, pp. 1464-1471, 1999.

12. J. F. Wood, "The functional properties of feed raw materials and their effect on the production and quality of feed pellets," Anim. Feed Sci. Technol., vol. 18, no. 1, pp. 1-17, 1987.

13. E. Angulo and J. Brufaub, "Effect sepiolite on pellet durability in feeds differing in fat fibre content.pdf," Anim. Feed Sci. Technol., vol. 53, no. 94, pp. 233-241, 1995.

14. M. Thomas, T. Van Vliet, and A. F. B. Van Der Poel, "Physical quality of pelleted animal feed 3 . Contribution of feedstuff components," Anim. Feed Sci. Technol., vol. 70, no. 1-2, pp. 59-78, 1998.

15. I. Journal and O. F. Engineering, "International journal of engineering sciences \& research technology," vol. 4, no. 1, pp. 2-5, 2015.

16. J. Kers et al., "Polümeersetest jäätmetest pressitud brikettide füusikalismehaaniliste ja põlemiskarakteristikute määramine," Est. J. Eng., vol. 16, no. 4, pp. 307-316, 2010.

17. S. W. Wijianto, Subroto, "Karakteristik Mekanik Briket Kokas Lokal Dengan Variasi Jenis Perekat," pp. 45-51, 2015.

18. R. I. Muazu and J. A. Stegemann, "Biosolids and microalgae as alternative binders for biomass fuel briquetting," Fuel, vol. 194, pp. 339-347, 2017.

19. E. F. Aransiola, T. F. Oyewusi, J. A. Osunbitan, and L. A. O. Ogunjimi, "Effect of binder type, binder concentration and compacting pressure on some physical properties of carbonized corncob briquette," Energy Reports, vol. 5, pp. 909-918, 2019.

20. M. G. Montiano, A. M. Fernández, E. Díaz-Faes, and C. Barriocanal, "Tar from biomass/coal-containing briquettes. Evaluation of PAHs," Fuel, vol. 154, pp. 261-267, 2015.

21. A. D. Anggono, W. A. Siswanto, and B. Omar, "Hybrid die compensation method to accommodate springback error in sheet metal," in AIP Conference Proceedings, 2011, vol. 1383, pp. 1056-1063.

22. A. D. Anggono, N. Ernawan, and T. W. B. Riyadi, "Analysis of mechanical and metallographic properties on the joining between aluminum and brass by using the brazing method," Int. J. Emerg. Trends Eng. Res., vol. 8, no. 2, pp. 440-446, 2020. 